\title{
A VARANID LIZARD (SQUAMATA: VARANIDAE) FROM THE EARLY EOCENE OF KIRGHIZIA
}

\author{
Alexander O. Averianov ${ }^{1}$ and Igor G. Danilov ${ }^{1}$
}

Submitted August 21, 1997.

Three vertebrae of a large varanid lizard from the early Eocene Andarak 2 locality in Kirghizia are described. The sacral and proximal postsacral vertebrae are each characterized by a short dorso-ventrally deep centrum and a neural arch lacking the neural spine. The material is assigned to ?Saniwa sp., probably representing a new taxon of Varanidae.

Keywords: Saniwa, Varanidae, early Eocene, Kirghizia.

The fossils described in this paper come from the early Eocene Andarak 2 locality (Averianov, 1994 and references therein) in the northern foot-hills of the Turkestan Range in Fergana Valley, Kirghizia. One isolated varanid vertebra from the same locality and strata was assigned previously to ?Varanus sp. (Reshetov et al., 1978; Lungu et al., 1983), questionably to Varanus (Chkhikvadze, 1984), to Varanus sp. (Zerova and Chkhikvadze, 1984), or to "a large lizard probably related to Varanidae" (Zerova and Chkhikvadze, 1986), but it was never described or figured. The attribution of this Eocene material to the Recent genus seems to be improbable just because of the ancient geological age of the former (see also Clos, 1995). According to the last-named author, the oldest certain record of the genus Varanus is $V$. rusingensis from the early Miocene of Kenya.

Three additional vertebrae collected by the authors from the Andarak 2 locality and described here permit a more accurate generic determination for this Eocene varanid.

\section{Squamata Oppel, 1811}

Anguimorpha Furbringer, 1900

Varanidae Gray, 1827

Saniwa Leidy, 1870

?Saniwa sp.

(Figs. 1-2)

Material. Three vertebrae, ZISP PH ${ }^{2} \quad 10 / 1$, $11 / 1$, and $12 / 1$.

\footnotetext{
${ }^{1}$ Zoological Institute, Russian Academy of Sciences, Universitetskaya nab. 1, St. Petersburg 199034, Russia.

2 ZISP PH, Zoological Institute, Russian Academy of Sciences, St. Petersburg, Paleoherpetological Collection.
}

Description. ZISP PH 12/1 is the left portion of a trunk vertebra (Fig. $2 g, h$ ). The vertebral centrum is relatively elongated and tapers considerably posteriorly. The cotylus is shallow and oriented anteroventrally. The diapophysis is represented by a vertical facet low on the anterior portion of the centrum and is directed ventrolaterally. The ventral surface of the centrum is transversely convex. The neural canal is relatively large. The neural arch starts between the prezygapophyses. There is a weak pseudozygosphene at the base of the neural arch.

ZISP PH $11 / 1$ is the second sacral or first postsacral (caudal) vertebra (Fig. 1; Fig. 2f). The centrum is very short, broad, compressed dorsoventrally, and slightly tapering. The precondylar constriction is weak. The cotylus is deep and oriented anteriorly and slightly ventrally. There are no ridges for caudal chevrons. The ventral surface of the centrum is deeply concave along the longitudinal axis. The left diapophysis is broken, but its base is robust and anteroposteriorly expanded. The right diapophysis is rather short, directed laterally and slightly posteriorly. The diapophyses occupy more than a half of the centrum length. There are no traces of a contact with the ilium. The neural arch is low, narrow and anteroposteriorly short. The neural canal is very small. The zygapophyses are well developed. The pseudozygosphene is absent, that is usual for sacral vertebrae in Saniwa (Gilmore, 1928). The roof of the neural canal is placed entirely posterior to the prezygapophyses. The dorsal surface of the neural arch is flat and nearly parallel to the centrum. The neural spine is almost absent.

ZISP PH $10 / 1$ is an anterior caudal vertebra (Fig. $2 a-e$ ). It is very similar in morphology to 


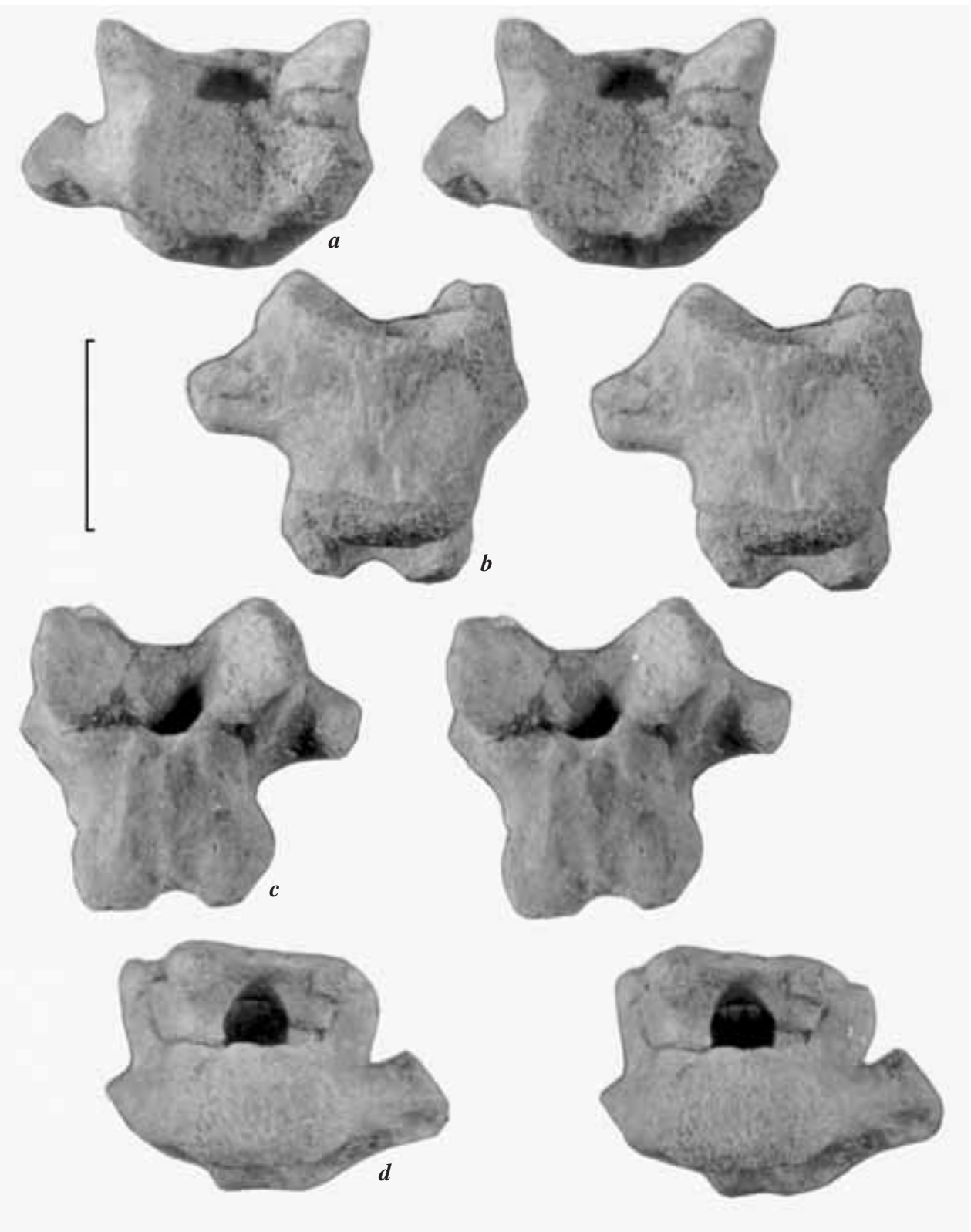

Fig. 1. Second sacral or first postsacral vertebra (ZISP PH 11/1) of ?Saniwa sp. from the Lower Eocene of Andarak 2, Kirghizia (stereopairs). $a$, Anterior; $b$, ventral; $c$, dorsal; $d$, posterior views. Scale bar is $1 \mathrm{~cm}$.

ZISP PH $11 / 1$. It differs in having the following characters: a more anteriorly oriented cotyle, two short but prominent ridges (haemopophyses) for caudal chevrons on the ventral surface of the centrum, a ventrally concave (in transverse section) centrum, more antero-posteriorly expanded diapophyses, and a flatter dorsally neural arch. The anterior part of the neural arch is broken.

Comparison. The anterior postsacral vertebrae from Andarak 2 differs from those in known species of Eocene Saniwa from North America (Gilmore, 1922, 1928) and Recent Varanus in having a shorter 


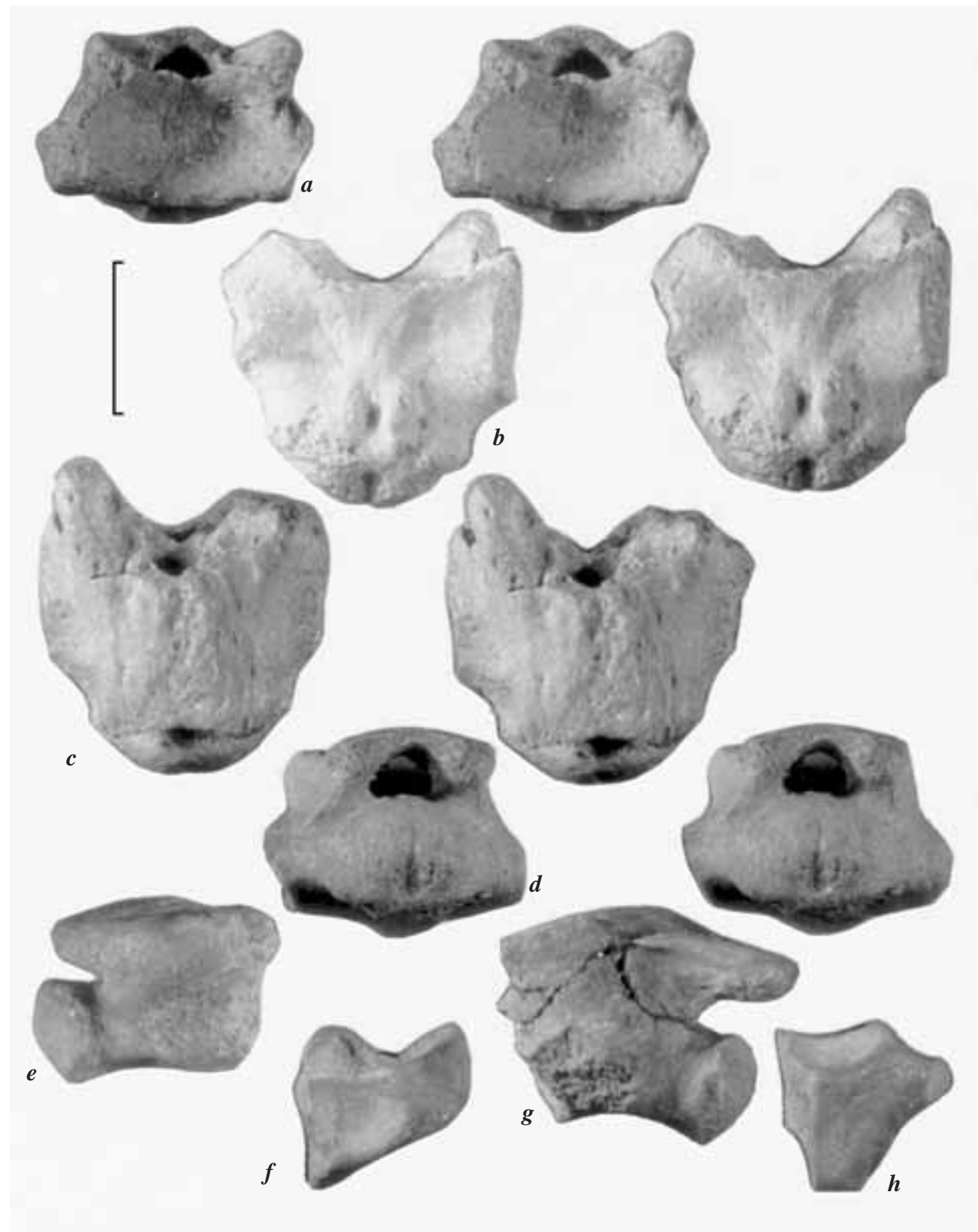

Fig. 2. Anterior postsacral ( $a-e$; ZISP PH 10/1), second sacral or first postsacral $(f ;$ ZISP PH $11 / 1)$ and trunk $(g, h$; ZISP PH $12 / 1)$ vertebrae of ?Saniwa sp. from the Lower Eocene of Andarak 2, Kirghizia ( $a-d)$ stereopairs). $a, g$, Anterior; $b, h$, ventral; $c$, dorsal; $d$, posterior; $e, f$, lateral views. Scale bar is $1 \mathrm{~cm}$.

centrum and in lacking the neural spine. In Saniwa, as in the Andarak 2 vertebrae, the anterior postsacral vertebrae bear weaker neural spines than those of Varanus (Estes, 1983). The Andarak varanid material also differs from Varanus in having a dorsoventrally deeper centrum, an almost straight or slightly incised posterior margin of the neural arch, a weak precondylar constriction on the anterior caudals, and a pseudozygosphene on the trunk vertebrae. The pseudozygosphene also occurs in Saniwa, but here it is usually 
much better developed, forming the anterior prominence of the neural arch (Gilmore, 1928; Hoffstetter, 1969).

In the necrosaurid "Saniwa" feisti from the middle Eocene of Germany (Stritzke, 1983) the trunk and proximal caudal vertebrae bear high neural spines.

\section{DISCUSSION}

The vertebrae described above are assigned to the Varanidae because they have the following characters (after Romer, 1956): 1) a centrum tapering posteriorly; 2) precondylar constriction; 3 ) a ventrally facing cotyle; 4) a large and flared condyle.

Varanidae is a monophyletic clade of anguimorph lizards that had originated most probably in Asia (Borsuk-Bialynicka, 1991b). The oldest varanids are known from the Campanian (Djadokhta and Barun Goyot formations) of Mongolia and China, and are accompanied by a number of basal platynotan genera (Borsuk-Bialynicka, 1991a; Norell et al., 1992; Gao and Hou, 1996). One trunk vertebra from the Campanian Barun Goyot Formation at the Khermeen-Tsav locality, Mongolia (Alifanov, 1993; Fig. 3) was referred to the Saniwa sp. A similar specimen was found in the Campanian Djadokhta formation at the Bayan Mandahu locality, China (Gao, Hou, 1996; Fig. 7c, d). These Mongolian and Chinese Cretaceous vertebrae differ from the Eocene vertebrae of ?Saniwa sp. described here in having a more posteriorly tapering centrum, a more distinct precondylar constriction, by the presence of a neural spine, and in having a more distinct pseudozygosphene.

Besides Andarak 2, isolated vertebrae were reported from some other Paleogene localities in Asia: Tsagan-Khushu (Bumban Member of the Naran Bulak Formation, Lower Eocene, Mongolia) (Alifanov, 1993) and Kiin-Kerish (Kusto Formation, Lower Oligocene, Kazakhstan) (Chkhikvadze, 1985; Zerova and Chkhikvadze, 1986). Undescribed remains of Saniwa sp. and Varanus sp. were also reported from unnamed localities in the middle Eocene and Lower Oligocene of Mongolia (Alifanov, 1995). Attribution of the isolated varanid vertebrae from the Paleogene and even Cretaceous of Mongolia to the Miocene-Recent genus Varanus (Alifanov, 1995) is questionable. The only figured specimen, from the Tsagan-Khushu locality (Alifanov, 1993, Fig. 4), bears an incipient but distinct pseudozygosphene and a long base of the neural spine. Both traits are characteristic of Saniwa (Gilmore, 1928; Estes, 1983). This specimen is similar to ZISP PH 12/1 from Andarak 2.

The vertebrae described here as ?Saniwa sp. differ in some properties from those known for Saniwa: the former have a shorter and dorsoventrally deeper centrum and lack a neural spine. Most probably they belong to a new species of Saniwa, or a new genus of Varanidae.

Acknowledgments. We are grateful to Dr. M. Godinot for assistance in the field, to Prof. J. David Archibald, and Dr. Magdalena Borsuk-Bialynicka for reading the manuscript, correcting the English, and making useful comments. The work was fulfilled using "Scientific Collections of the Zoological Institute, Russian Academy of Sciences," which is technically supported by the Science and Technology Commitee of the Russian Federation (Reg. No. 97-03-16).

\section{REFERENCES}

Alifanov V. R. (1993), "Some peculiaties [sic] of the Cretaceous and Palaeogene lizard faunas of the Mongolian People's Republic," Kaupia, 3, 9 - 13.

Alifanov V. R. (1995), Fossil Teioidea of Asia and Early Stages of Evolution of Lizards, Moscow, pp. 1-26 [in Russian].

Averianov A. O. (1994), "Early Eocene mimotonids of Kirghizia and the problem of Mixodontia," Acta Palaeontol. Polonica, 4, 393 - 411.

Borsuk-Bialynicka M. (1991a), "Cretaceous lizard occurrences in Mongolia," Cretaceous Res., 12, 607 - 608.

Borsuk-Bialynicka M. (1991b), "Questions and controversies about saurian phylogeny, Mongolian perspective," in: Z. Kielan-Jaworowska, N. Heintz, and H. A. Nakrem (eds.), Ext. Abstrs. of th Fifth Symp. of Mesozoic Terrestrial Ecosystems and Biota. Contributions from the Paleontological Museum, University of Oslo, No. 364, pp. 9 - 10.

Chkhikvadze V. M. (1984), "New species of tortoise from the Middle Eocene of Fergana," Paleontol. Sb., 21, 74 - 78 [in Russian].

Chkhikvadze V. M. (1985), "Preliminary results of study of Tertiary amphibians and squamate reptiles of Zayssan Depression," Vopr. Gerpetol., 6, 234-235 [in Russian].

Clos L. M. (1995), “A new species of Varanus (Reptilia: Sauria) from the Miocene of Kenya," J. Vert. Paleontol., 15, $254-267$. 
Estes R. (1983), Sauria Terrestria. Amphisbaenia. Handbuch der Palaoherpetologie, Stuttgart - New York.

Gao Keqin and Hou Lianhai (1996), "Systematics and taxonomic diversity of squamates from the Upper Cretaceous Djadochta Formation, Bayan Mandahu, Gobi Desert, People's Republic of China," Can. J. Earth Sci., 33, $578-598$.

Gilmore C. W. (1922), "A new description of Saniwa ensidens Leidy, an extinct varanid lizard from Wyoming," Proc. US Nat. Mus., 60, $1-27$.

Gilmore C. W. (1928), "Fossil lizards of North America," Nat. Acad. Sci. Memoir, 22, 1 - 197.

Hoffstetter R. (1969), "Presence de Varanidae (Reptilia, Sauria) dans le Miocene de Catalogne. Considerations sur l'histoire de la famille," Bull. Mus. Nat. d'Hist. Natur. Ser. 2, 40, $1051-1064$.

Lungu A. N., Zerova G. A., and Chkhikvadze V. M. (1983), "Primary evidence on the Miocene Varanus of the North Black Sea littoral [sic]," Soobshch. Akad. Nauk Gruz. SSR, 110, 417 - 420 [in Russian].
Norrell M. A., McKenna M. C., and Novacek M. J. (1992), "Estesia mongoliensis, a new fossil varanoid from the Late Cretaceous Barun Goyot Formation of Mongolia," Am. Mus. Novitates, 3045, 1 - 24.

Reshetov V. Y., Shevyreva N. S., Trofimov B. A., and Chkhikvadze V. M. (1978), "On the vertebrates of the Andarak locality (Middle Eocene)," Byull. Mosk. Obshch. Ispyt. Prirody. Otd. Geol., 53(3), 151 - 152 [in Russian].

Romer A. S. (1956), The Osteology of the Reptiles, Chicago.

Stritzke R. (1983), "Saniwa feisti n. sp., ein Varanidae (Lacertilia, Reptilia) aus dem Mittel-Eozän von Messel bei Darmstadt," Senckenberg. Lethaia, 64, 497 - 508.

Zerova G. A. and Chkhikvadze V. M. (1984), "Review of Cenozoic lizards and snakes of the USSR," Izv. Akad. Nauk Gruz. SSR. Ser. Biol., 10, 319 - 126 [in Russian].

Zerova G. A. and Chkhikvadze V. M. (1986), "Neogene varanids of the USSR," in: Z. Roček (ed.), Studies in Herpetology, Prague, pp. 689 - 694. 